\title{
IMMUNITY OF CHARITABLE INSTITUTIONS TO TORT LIABILITY: AN ERODING DEFENSE
}

$T$

HE DOCTRINE WHICH EXEMPTS charitable institutions from tort liability $^{1}$ met with new rebuff in the recent case of Noel $v$. Menninger Foundation ${ }^{2}$ There, the plaintiff, seeking damages for allegedly negligently caused injury, had been stymied in the trial court by a demurrer which had been sustained on the ground that the defendant, as a charitable institution, was immune from such suits. The Kansas Supreme Court, however, overruling a long line of precedent, ${ }^{3}$, reversed, holding that the policy reasons justifying this immunity no longer obtained and, further, that it contravened the Kansas Bill of Rights."

The history of this doctrine of immunity is a checkered one. First enunciated in England in $1846,{ }^{5}$ it was shortly thereafter repudiated, ${ }^{6}$ only to be adopted in Massachusetts in 1876,7 whence it spread rapidly throughout this country. 8 Its growth was nurtured by feelings of judicial solicitude for financially weak but vitally needed charitable organizations whose operations, it was feared, might otherwise be seriously impeded. ${ }^{9}$ Valid though this concern may then have been, however, it would appear to be less compelling today when many charitable institutions have grown into enormous businesses, owning vast amounts of property, ${ }^{10}$ much of it tax free, and when liability insurance has

${ }^{1}$ See generally Prosser, TORTs, $\S$ I08 (I941); Appleman, Tort Liability of Charitable Institutions, 22 A.B.A.J. 48 (1936); Scott, Tort Liability of Hospitals, 77 TENN. L. REv. 838 (1943); Note, 30 N.C.L. REV. 67 (1951).

${ }^{2}$ I 75 Kan. 751, 267 P.2d 934 (1954).

${ }^{3}$ Nicholson v. Atchison, Topeka and Santa Fe Hospital Ass'n, 97 Kan. 480, $x 55$ Pac. 920 (19r6); Davin v. Kansas Medical, Missionary and Benevolent Ass'n, ro3 Kan. 48, I72 Pac. 1002 (1918); Webb v. Vought, I27 Kan. 799, 275 Pac, I70 (1929); Ratliffe v. Wesley Hospital, I35 Kan. 306, xo P.2d 859 (1932); Leeper v. Salvation Army, I58 Kan. 396, 147 P.2d 702 (1944).

"All persons, for injuries snffered in person, ... shall have remedy by due course of law ... without delay." Kansas BILl OF Rights $\S \times 8$.

${ }^{5}$ Feoffees of Heriot's Hospital v. Ross, 12 Cl. \& F. 507, 8 Eng. Rep. 1508 (H.L. I846).

'Mersey Docks Trustees v. Gibbs, I I H.L. Cas. 686, I I Eng. Rep. I500 (1866).

${ }^{7}$ McDonald v. Massachusetts General Hospital, 120 Mass. 432 (1876).

${ }^{8}$ See Note, 25 A.L.R.2d 29, I42 et seq. (1952).

'See, e.g., Noel v. Menninger Foundation, 175 Kan. 751, 267 P.2d 934, 939 (1954).

${ }^{10}$ See, e.g., Silvia v. Providence Hospital, i4 Cal.2d 762, 97 P.2d 798 (1939) wherein there are detailed the assets of defendant hospital which was only one of several charitable institutions run by a central organization. 
become so readily procurable. Nevertheless, the doctrine of immunity has, to a large extent, lingered on.11

Apart from policy, various legal theories have been adduced in support of this doctrine. It has been urged, for example, that the concept of respondeat superior should not render a charitable institution liable for the torts of its employees since it derives no profit from their services. ${ }^{12}$ This would seem to be quite irrelevant, however, as the availability of respondeat superior as the basis of an employer's tort liability has traditionally depended on other factors. ${ }^{13}$ A "trust fund" theory has also been invented, under which it has been argued that the diversion of funds held in trust by a charitable institution to the payment of a judgment for negligence would thwart the donor's intent where no provision for such payment appears in the indenture. ${ }^{14}$ It should be noted, however, that the relationship of a corporation, whether charitable or not, to its property is not precisely that of a legal trustee to his trust funds; ${ }^{15}$ and even in this latter relationship, the trust fund has no ultimate immunity from a tort judgment, but a mere technical immunity because of the legal estate of the trustee therein. ${ }^{16}$ Similarly specious are the assertions that a person who avails himself of charitable services constructively waives his right of action for, and assumes the risk of, negligence ${ }^{17}$ or that charitable institutions, because of their intimate association with the state in performing public welfare functions, share the immunity of the state and its agencies. ${ }^{18}$ These fictions do not accord with common experience and beliefs, and have not widely been

\footnotetext{
${ }^{11}$ See, e.g., note 22 and accompanying text infra.

${ }^{12}$ E.g., Hearns v. Waterbury Hospital, 66 Conn. 98, 33 Atl. 595 (1895); Farrigan v. Pevear, 193 Mass. 147, 78 N.E. 855 (1906).

${ }^{13}$ See MECheM, OUTLINES OF THE LAW OF AGENCY $\S \S 349-63$ (4th ed. 1952). The author points out that respondeat superior has been justified on the ground that the principal has the power of control over the agent as well as on the ground that the principal derives profit from the acts of the agent; moreover, he suggests that the inevitability of harm arising from doing business with agents is the most important factor giving vitality to the doctrine. See also Ray v. Tucson Medical Center, 72 Ariz. 22, 230 P.2d 220 (195I); Session v. Thomas D. Dee Memorial Hospital Ass'n, 94 Utah 460,78 P.2d 645 (1938).

${ }^{14}$ E.g., Parks v. Northwestern University, 218 Ill. 381, 75 N.E. 991 (1905); Cook v. John N. Norton Memorial Infirmary, 180 Ky. 331, 202 S.W. 874 (1918).

${ }^{15}{ }_{3}$ SCOTT, TRUSTS $\$ 348.1$ (1939).

${ }^{10} 2 \mathrm{id}$., $\S \S 264,27 \mathrm{IA}$ (1939).

${ }^{17}$ E.g., Wilcox v. Idaho Falls Latter Day Saints Hospital, 59 Idaho 350, 82 P.2d 849 (1938); Cook v. John N. Norton Memorial Infirmary, 180 Ky. 331, 202 S.W. 874 (1918).

${ }^{18}$ E.g., Fordyce v. Woman's Christian National Library Ass'n, 79 Ark. 550, 96 S.W. x55 (1906); University of Louisville v. Hammock, 127 Ky. 564, 106 S.W. 219 (1907).
} 
entertained by the courts. ${ }^{19}$ Finally, it has been observed that a policy so firmly entrenched should be altered only by legislative action. ${ }^{20}$ But there would appear to be no sound reason in law or logic why a doctrine originally promulgated by the courts ${ }^{21}$ should not, with equal validity, be cast aside by them in favor of a more salutary public policy.

The theories upon which the doctrine has been rested are thus as intellectually unsatisfying as the results of its application. And although the doctrine is still embraced uncritically in a number of jurisdictions, ${ }^{22}$ dissatisfaction with its operation is reflected in the modifications of its application in many jurisdictions.

By way of modification, some states have permitted charitable institutions but a limited immunity by excluding non-trust property from the execution of a tort judgment. ${ }^{23}$ And frequently immunity has been made to depend on the status of the plaintiff-it being held not to extend to torts committed against a servant ${ }^{24}$ or a stranger, i.e., one not a recipient of benefit from the institution. ${ }^{25}$ Further, a few courts, al-

${ }^{10}$ E.g., Ray v. Tucson Medical Center, 72 Ariz. 22, 230 P.2d 220 (195 I) (rejecting the doctrine of implied waiver and assumption of risk; Lichty v. Carbon County Agr. Ass'n, 3I F. Supp. 809 (M.D. Pa. 1940) rejecting the doctrine of immunity because of close association with the state). See also Note, 25 A.L.R.2d 29, 67-68 (1952).

${ }^{20}$ E.g., Foley v. Wesson Memorial Hospital, 246 Mass. 363 , I41 N.E. I1 3 (1923); DeGroot v. Edison Institute, 306 Mich. 339, I0 N.W.2d 907 (1943).

${ }^{21}$ See notes 5-8 and accompanying text supra.

${ }^{22}$ Ten jurisdictions accord charitable institutions complete immunity from tort liability. Michael v. St. Paul Mercury Indemnity Co., 92 F. Supp. 140 (W.D. Ark. 1950); Williams' Adm'x v. Church Home for Females, $223 \mathrm{Ky} .355,3$ S.W.2d 753 ( 1928 ); Jensen v. Maine Eye and Ear Infirmary, Io7 Me. 408, 78 Atl. 898 (1910); Howard v. South Baltimore General Hospital, 191 Md. 6x7, 62 A.2d 574 (1948); Bearse v. New England Deaconess Hospital, 321 Mass. 750, 72 N.E.2d 743 (1947); Dille v. St. Luke's Hospital, 355 Mo. 436, 196 S.W.2d 615 (1946); Gregory v. Salem General Hospital, 175 Ore. 464, x 53 P.2d 837 (1944); Bond v. Pittsburgh, 368 Pa. 404, 84 A.2d 328 (1951); Byrd v. Blue Ridge Rural Electric Cooperative, Inc., 118 F. Supp. 868 (W.D.S.C. 1954); Schau v. Morgan, 24I Wis. 334, 6 N.W.2d 212 (1942).

${ }^{23}$ Moore v. Moyle, 405 Ill. 555, 92 N.E.2d 81 (1950); McLeod v. St. Thomas Hospital, 170 Tenn. 423, 95 S.W.2d 917 (1936); St. Luke's Hospital Ass'n v. Long, 125 Colo. 25, 240 P.2d 917 (1952); Robertson v. Executive Committee of Baptist Convention, 55 Ga.App. 469, 190 S.E. 432 (1937).

${ }^{24}$ Hordern v. Salvation Army, 199 N.Y. 233, 92 N.E. 626 (1910); Cowano v. North Carolina Baptist Hospitals, 197 N.C. 41 , 247 S.E. 672 (1929); Gable v. Salvation Army, I86 Okla. 687, 100 P.2d 244 (1940); Medical and Surgical Memorial Hospital v. Cauthorn, 229 S.W.2d 932 (Tex. Civ. App. 1949).

${ }_{25}$ Alabama Baptist Hospital Board v. Carter, 226 Ala. I09, 145 So. 443 (1932); Cohen v. General Hospital Soc., II3 Conn. I88, 154 Atl. 435 (1931); Winona Technical Institute v. Stolte, 173 Ind. 39,89 N.E. 393 (1909); Jewell v. St. Peter's Parish, ro N.J. Super. 229, 76 A.2d 917 (1950); Walker v. Memorial Hospital, I 87 Va. 5, 45 S.E.2d 898 (1948). On the other hand, most of these jurisdictions 
though denying recovery against a charitable institution in tort, will allow it on a breach of contract theory, ${ }^{26}$ or permit negligent service to be set up as a defense to an action for the value of the services rendered. ${ }^{27}$ Other courts have granted recovery when the tort is committed in the course of non-charitable or commercial activities even though the activities are carried on to obtain revenue to be used for charitable purposes. ${ }^{28}$ Two states, moreover, have passed statutes which give a negligently injured party a direct action against the institution's insurance company and prohibit the company from raising the defense of charitable immunity. ${ }^{29}$ Another ameliorative technique employed by some courts has been to distinguish between corporate negligence-neglect on the part of officers and managers-and negligence on the part of subordinate employees, allowing recovery for the former. ${ }^{30}$

The Noel case and other recent decisions, ${ }^{31}$ on the other hand, suggest a trend beyond mere amelioration towards complete rejection of the immunity doctrine. And where the courts have been unfettered by contrary precedent, this proclivity has been even more marked. ${ }^{32}$ This would seem to reflect the growing recognition of the obsolescence of the

have conferred immunity with respect to torts committed against a beneficiary, and where a hospital is the tort-feaser the mere fact that the injured patient paid in whole or in part for his services will not necessarily remove him from the status of beneficiary. See, e.g., Powers v. Massachusetts Homeopathic Hospital, 109 Fed. 294 (1st Cir. I901), cert. denied, I 83 U.S. 695 ( I901). But cf. Nicholson v. Good Samaritan Hospital, 145 Fla. 360, I 99 So. 344 (1940) where the court distinguished between paying and non-paying patients and allowed recovery to former.

${ }^{20}$ E.g., Tucker v. Mobile Infirmary Ass'n, I9I Ala. 572, 68 So. 4 (1915); Parrish v. Clark, I07 Fla. 598 , 145 So. 848 (1933).

${ }^{27}$ Beverly Hospital v. Early, 292 Mass. 201, I97 N.E. 641 (1935).

${ }^{28}$ McKay v. Morgan Memorial Co-op. Industries and Stores, Inc, 272 Mass. I2 I, I72 N.E. 68 (1930) (operated a series of stores); School Dist. v. Philadelphia, $367 \mathrm{~Pa}$. 180, 79 A.2d 433 (195I) (engaged in mining); Pearlstein v. A. M. McGregor Home, 79 Ohio App. 526, 73 N.E.2d 106 (I947) (operated apartment house); Rhodes v. Millsaps College, I79 Miss. 596, I76 So. 253 (I937) (rented part of a building as office space).

${ }^{29}$ ARK. STAT. \$ 66-517 (1947); MD. ANN. CODE art. 48A, § 82 (1947).

${ }^{36}$ Evans v. Lawrence and Memorial Associated Hospitals, 133 Conn. 3 II, 50 A.2d 443 (r946); Medical and Surgical Memorial Hospital v. Cauthorn, 229 S.W.2d 932 (Tex. Civ. App. 1949).

${ }^{31}$ Ray v. Tucson Medical Center, 72 Ariz. 22, 230 P.2d 220 (I95I); Haynes v. Presbyterian Hospital Ass'n, 24 I Iowa 1269, 45 N.W.2d I5I (1950); St. Paul Mercury Indemnity Co. v. St. Joseph's Hospital, 212 Minn. 558, 4 N.W.2d 637 (1942); Rickbeil v. Grafton Deaconess Hospital, 74 N.D. 525, 23 N.W.2d 247 (1946); Brigham Young University v. Lillywhite, I 8 F.2d 836 ( roth Cir. 194I).

${ }^{32}$ Durney v. St. Frances Hospital, 83 A.2d 753 (Del. Super. 195I); Foster v. Roman Catholic Diocese, I 6 Vt. I24, 70 A.2d 230 (1950); Malloy v. Fong, 37 Cal.2d 356, 232 P.2d 24I (195I); President and Directors of Georgetown College v. Hughes, " 30 F.2d 810, (D.C. Cir. I 942 ). 
doctrine and its adverse social consequences, and echo the sentiments of Justice Rutledge who, after reviewing the history of the doctrine, remarked that even though it may have been validly conceived, the doctrine of immunity "should go and the object of the charity be placed on a par with all others. ${ }^{333}$

JoHN A. REED

${ }^{33}$ President and Directors of Georgetown College v. Hughes, r3o F.2d 810, 827 (D.C. Cir. r942). 